\title{
FYVE, RhoGEF and PH Domain-Containing Protein 4
}

National Cancer Institute

\section{Source}

National Cancer Institute. FYVE, RhoGEF and PH Domain-Containing Protein 4. NCI

Thesaurus. Code C104381.

FYVE, RhoGEF and PH domain-containing protein 4 (766 aa, $\sim 87 \mathrm{kDa}$ ) is encoded by the human FGD4 gene. This protein plays a role in regulation of the actin cytoskeleton and cell shape. 